\title{
REVIEW
}

\section{Research on the Way to Realize Humanistic Care in College Students' Ideological and Political Education}

\section{Li Wang*}

School of Marxism, Nanjing Normal University, Nanjing, Jiangsu, 210023, China

\begin{tabular}{|c|c|}
\hline ARTICLE INFO & ABSTRACT \\
\hline Article history & The report of the Eighteenth National Congress of the Communist Party \\
\hline Received: 13 June 2019 & of China puts forward the connotative development of higher education. \\
\hline Revised: 1 July 2019 & $\begin{array}{l}\text { For ideological and political education, it is to realize the humanistic } \\
\text { care of Ideological and political education. Humanistic care, as a unique }\end{array}$ \\
\hline Accepted: 9 October 2019 & "general education" in Chinese universities, is the basis for improving \\
\hline Published Online: 16 October 2019 & $\begin{array}{l}\text { the effectiveness of Ideological and political education. It is an important } \\
\text { standard for the connotative development of higher education to construct }\end{array}$ \\
\hline $\begin{array}{l}\text { Keywords: } \\
\text { Ideological and political education in colleges }\end{array}$ & $\begin{array}{l}\text { a path to realize the humanistic care of Ideological and political education } \\
\text { from the three elements of educators, educatees and educational environ- } \\
\text { ment. }\end{array}$ \\
\hline
\end{tabular}

\section{Introduction}

The report of the 17th National Congress of the Communist Party of China put forward for the first time: "Strengthening and improving ideological and political work, paying attention to humanistic care and psychological guidance, and handling interpersonal relations in the right way". The report of the Eighteenth National Congress of the CPC further pointed out: "Strengthening and improving ideological and political work, paying attention to humanistic care and psychological guidance, and cul-

tivating self-esteem, self-confidence, rational peace and positive social mentality." These expositions point out the direction for further strengthening and improving the ideological and political work and improving the pertinence and effectiveness of the ideological and political work. As an important part of Ideological and political work, college students' ideological and political education should incorporate humanistic care into it and run through it all the time. Especially under the background of social transformation, social structure change, pluralistic values of social members and constant contradictions and conflicts,

*Corresponding Author:

Li Wang,

Female, Nanjing, Jiangsu, lecturer, master's degree, mainly engaged in ideological and political education research, higher education management;

Correspondence address: School of Marxism, Nanjing Normal University, No. 1 Wenyuan Road, Xianlin University Town, Nanjing, Jiangsu, 210023, China:

E-mail:xuqqjs@126.com.

Fund Project:

The phase research results of the key project of the Jiangsu University Counselor Work: "Research on the Employment Competitiveness of Undergraduates in the background of the new normal of China's economy" (Project No.: 14FYHZD0714FYHZD07). 
in order to give full play to the due value of Ideological and political education of college students in cultivating a good mentality of "self-esteem, self-confidence, rational peace and positive progress", and to enhance the effectiveness of Ideological and political education of College students, it is necessary to integrate humanistic care as its own. The inevitable choice of development ${ }^{[1]}$. This study studied ways to Realize Humanistic Care in College Students' Ideological and Political Education.

\section{Value Appeal of Integrating Ideological and Political Education of College Students into Humanistic Care}

The ideological and political education of college students contains a profound humanistic wisdom and spirit, and has an inherent consistency with humanistic care. The process of College Students' ideological and political education is actually the process of providing humanistic care for students. Essentially, the ideological and political education of college students is a social educational activity to cultivate, shape, develop and perfect people. It shoulders the mission of paying attention to people's own development, interpreting the ultimate meaning of life and promoting people's allround development. This corresponds to the concern and satisfaction of the basic state of human existence, human needs and human subjectivity, respect and concern for human dignity, personality and value, and affirmation and pursuit of human all-round development embodied in humanistic care. Therefore, to integrate humanistic care into the ideological and political education of college students and promote their all-round and harmonious development is the proper meaning of Ideological and political education of College students. The ideological and political education of college students should respond to the realistic requirements of social development, meet the actual needs of college students' development, train college students to be qualified builders and reliable successors of socialism with all-round development of morality, intelligence, physique and beauty, and should incorporate humanistic care into it and run through it all the time ${ }^{[2]}$.

\section{Ways to Realize Humanistic Care in Col- lege Students' Ideological and Political Edu- cation}

\subsection{Promoting Educators' Humanistic Concern is the First Link in Ideological and Political Educa- tion}

Educators are in a leading position in education. This requires educators to establish their own value orientation.
The same teaching content in different educators often presents different values. As the philosopher Hegel said, the same maxim, spoken in the mouth of a weathered old man and in the mouth of a child, has a different meaning. "The religious truths that the old people speak, although the children can speak, for the old people, these religious truths contain the meaning of their whole life." Because the old man is a person with rich life experience, when he utters this motto, there is a real experience in it. That is to say, a person's knowledge background and the values he already has are a guide to what kind of values we will shape. The value background of an educator decides what kind of value he will convey to the same educational content, whether it is the direction of justice or the direction of evil, which depends on the nature of the educator's own values. Therefore, the humanistic care of educators themselves is the decisive factor to control the content of education. Therefore, the same textbook in different educators, there will be loaded with different levels of values, or even the opposite ${ }^{[3]}$.

\subsection{Educators' Own Humanistic Accomplishment Can Always Be Subtly Perfused In the Education- al Content}

This is reflected in their ideological realm in the process of education and teaching. If an educator has lofty humanistic care, he will connect the content of education with lofty humanistic care, so as to guide the educated to this kind of humanistic care. On the contrary, if an educator fails to reach the level of noble humanistic care, noble humanistic care can not be conveyed through the educational content. Therefore, the individual style of educators is always involved in the process of education and teaching. In the final analysis, the individual style of an educator is determined by his realm of humanistic concern. The nobler his ideological realm is, the more pure his thoughts are and the closer his educational style is to nobility. Of course, it is not enough for educators to have noble ideological realm, which is only the subjective condition to realize the humanistic care of Ideological and political education. In addition, it is necessary for educators to establish a teaching method or mode of humanistic care. At present, academia has put forward situational teaching method, situational teaching method, experiential teaching method and other methods in the exploration of teaching methods. These methods help to integrate the metaphysical realm of humanistic care into the educational content, so as to realize the humanistic care of Ideological and political education. Whether these teaching methods can really play their educational function of humanistic care depends on the educators' ability of rational thinking. If we lack the power of rational speculation, it will 
easily lead to a kind of "sensation" without logic, which seems to be a kind of education method conforming to humanistic concern on the surface, but in essence, because of the lack of the power of rational speculation, the content of the lecture has no depth, nor the shock and impact of thought. Therefore, for educators, to realize the humanistic care of Ideological and political education, we need not only a noble ideological realm, but also a "reasonable" education method $^{[4]}$.

\subsection{Educated People Need to Make Adequate Ideological Preparations to Realize the Humanis- tic Care of Ideological and Political Education}

At present, many students still study ideological and political theory from the perspective of "knowledge theory", whose purpose is to cope with the examination. In fact, the essence of curriculum is not "knowledge" about moral cultivation and law, because all humanities education is not "knowledge education", which is different from natural science education in science and engineering. In the natural sciences, the content of our education can be regarded as "knowledge", but in the humanities, the content of our education is no longer "knowledge", but a kind of "thought" or "concept". Even if we can recite a lot of knowledge of ideology, morality and law, it does not necessarily form a "identity" of values. This is another important reason that restricts the effectiveness of Ideological and political education. We have set up four courses of Ideological and political education. Most college students learn these courses as "knowledge", and knowledge is only a kind of memory "reserve" for the educated. Whether these knowledge can be truly combined with college students' values, political beliefs, moral life and the meaning of life still needs college students themselves. Understanding and understanding need rational thinking and discrimination. Then, beyond the attitude of "epistemology", we should establish a learning attitude of humanistic concern. We can call this learning attitude of humanistic concern "the attitude of axiology". This learning attitude of humanistic concern is the "threshold" for educators to devote themselves to the study of Ideological and political education curriculum. In other words, whether college students can change their attitude towards ideological and political education from "epistemological attitude" to "axiological attitude" is the key factor for educators to enter the humanistic concern of Ideological and political education ${ }^{[5]}$.

\subsection{Change of University Educational Environ- ment}

We should first distinguish two different kinds of rational- ity: instrumental rationality and humanistic rationality. Instrumental rationality is the basis of natural science, while humanistic rationality is the condition of humanistic care. At present, China's higher education emphasizes more on the "technological power", while the "cultural power" is in a relatively weak position. The former relies on the instrumental rationality of higher education, while the latter relies on the humanistic rationality. Therefore, the state has put forward the cultural strategy of Flourishing Philosophy and Social Sciences and strengthening cultural soft power. Over the past 30 years of reform and opening up, China's economy has developed rapidly, and higher education undoubtedly plays an important role. Since the 18th National Congress of the Communist Party of China, the goal of deepening reform has been put forward. Therefore, higher education should achieve "connotative development". What is the connotative development of higher education? It is to make the scientific research achievements of universities not only improve in quantity, but also in quality. Science and technology itself is "value-neutral". Therefore, "connotative development" needs to take the achievements of science and technology into consideration on the basis of human values; otherwise, science and technology will lose its "connotation". In this sense, it is not enough for higher education to have only instrumental rationality, but also humanistic rationality. Therefore, how to use humanistic rationality to improve the educational environment of universities is an important factor influencing the realization of humanistic care in Ideological and political education. Shaping the spirit of humanistic rationality in modern universities is the third effective way to realize humanistic care in Ideological and political education in contemporary China. Ideological and political education based on humanistic concern is an important standard for the connotative development of contemporary Chinese higher education ${ }^{[6-10]}$.

\section{References}

[1] Zhang Zhao. Exploring the Ideological and Political Education of College Students from the Perspective of Humanistic Care[J]. Chizi, 2019(11):107.

[2] Feng Luning. Thoughts and Explorations on Ideological and Political Education of College Students from the Perspective of Humanistic Care[J]. Chizi, 2019(11):101.

[3] Yue Zongfeng. Infiltration Path of Humanistic Care in Ideological and Political Education of College Students[J]. Journal of Shandong Agricultural Engineering College, 2019, 36(4):151-152.

[4] Yuan Yue. Talking about Ideological and Political Education of College Students under Humanistic 
Care in the New Period[J]. Northern Literature (Midterm Journal), 2019(1):178.

[5] Deng Huiliang, Hu Yuying. Strategies for Integrating Ideological and Political Education into Humanistic Care for College Students[J]. New Course Research (Mid-Decade-Shuangshuang), 2018(6):16-17.

[6] Hua Shan. Talking about the Humanistic Care Path of College Students'Ideological and Political Education[J]. Intelligence, 2018(34):113.

[7] Hua Shan. Talking about the Humanistic Care Path of College Students'Ideological and Political Education[J]. Shanxi Youth, 2018(21):149.
[8] Mei Lisi. An Analysis of Ideological and Political Education of College Students from the Perspective of Humanistic Care $[\mathrm{J}]$. Education and Teaching Forum, 2019, (4):51-52.

[9] Li Hongli. Discussion on Humanistic Care of Ideological and Political Education of College Students in the Internet Era[J]. Yangtze River Series, 2019(1):231-232.

[10] Zhang Enzun. Analysis of the Application of Humanistic Concern in College Students' Ideological and Political Education[J]. Youth Years, 2019(11):145. 